\title{
STUDIES ON NUTRITION OF MUSHROOM: 1-EFFECT OF AMINO ACIDS AND VITAMIN B COMPLEX ON GROWTH AND PRODUCTIVITY OF OYSTER MUSHROOM
} \author{
El-Sayed, Hala A.*; E. I. El-Gamily*; N. M. Hassanine ${ }^{* *}$ and
} A. I. Mohammed ${ }^{\star \star}$ "Hort. Dept., Fac. Agric., Mansoura Univ. ${ }^{*}$ Veg. Res. Dept., Hort. Res. Inst., Agric. Res. Center

\begin{abstract}
This work was carried out in Private Farm at Kaffer Saker, Sharkia Governorate, during the period between 2009 and 2010 seasons to study the effect of application with amino acids and vitamin B complex to the rice straw substrate on the growth, yield and its components, physical characters and chemical constituents of oyster mushroom fruit bodies.

The obtained results showed that, mushroom cultivated on rice straw +vit. B complex at $200 \mathrm{ppm}+$ amino acids at 200 ppm gave the highest values of cap diameter, stipe diameter, stipe length and cap weight followed by rice straw + vitamin B complex 200 ppm. While, mushroom cultivated on rice straw + vitamin B complex at $200 \mathrm{ppm}$ gave the highest values of early yield/ bag, total yield/ bag, early yield / total yield \% and biological efficiency\% .

On the other hand, cultivation of mushroom on rice straw + vit. B complex at $400 \mathrm{ppm}+$ amino acids at $400 \mathrm{ppm}$ gave the highest values of nitrogen , phosphorus, potassium, dry matter and crude protein as well as total carbohydrates followed by rice straw + vit. B complex at 200 ppm + amino acids at 200 ppm.

On the contrary, cultivation oyster mushroom on rice straw only (control) produced the lowest values of all studied characters.

Keywords: Oyster mushroom, vitamin B complex, amino acids, biological efficiency, yield.
\end{abstract}

\section{INTRODUCTION}

The "Mushroom" word is used in all part of world to describe the fruiting bodies of saprophytic, mycorrhizal and parasites fungi, Oyster mushroom belongs to class: Basidiomycetes, sub class; Holobasidiomycetidae, order: Polyporales. They can be found in soils rich in organic matter and humus, moist wood, animal waste, etc., after heavy rain (with thunderstorm or not) or a sudden change of temperature and soon after a few hours or days they disappear, leaving no sign, but vegetative mycelium. There are at least 12,000 species of fungi that can be considered mushrooms, with at least 2000 species showing various degrees of edibility. Furthermore, over 200 species have been collected from the wild and used for various traditional medical purposes. About 35 mushroom species have been cultivated commercially, and of these, around 20 were cultivated on an industrial scale (DÜndar and Yildiz, 2009).The genus of pleurotus (oyster mushroom) comprises about 40 species (Jose and Janardhanan, 2000). They are ubiquitous, being found in both temperate and tropical parts of the world, and 
are now considered being the second most important cultivated mushroom in the world (Chang et al., 1981).

Growing oyster mushroom is became more popular through the world and had many advantages comparing with other cultures because of their ability to grow in a wide range of temperature its highly labor intensive, short duration crop life cycle and land saving beside to using the agricultural wastes as a medium for it's growth (Moda et al., 2005).

One of the world's biggest challenges is food insecurity. This problem is largely common in low- and middle-income countries which mainly have poor food production system and hence, suffer from serious malnutrition. Such countries must find ways of improving food production so as to feed vastly increasing human population. Mush-room cultivation could be a possible option to alleviate poverty and develop the life style of the vulnerable people (Imtiaj and Rahman, 2008).

Mushrooms cultivation offers benefit to market gardens when it is integrated into the existing production system by producing nutritious food at a profit, while using materials that would otherwise be considered "waste" (Beetz and Kustudia, 2004). This is because mushrooms contain many essential nutrients and they are found to solve dietary related health problems (Atikpo et al., 2008).

Vitamin $B_{1}$ (thiamine) is an organic compound that can be supplied to plant as seed soaking or as foliar spray to improve their growth and productivity (Oertli, 1987). Folic acid (vitamin $B_{9}$ ) has become the most prominent of Bcomplex vitamins despite its essential biochemical function in amino acids metabolism and nucleic acids synthesis (Andrew et al., 2000). Cobalamin (vitamin $B_{12}$ ) is necessary for the regulation of DNA synthesis during cell division (Smith et al., 2007). However, responses of plants to cobalamin or folic acid treatments in terms of growth and yield parameters have not been investigated to date.

Addition of vitamin B- complex $(100,200 \mathrm{and} 300 \mathrm{mg} / \mathrm{l})$ to wheat straw, paddy straw and leman grass straw as substrate to cultivated pleurotus sajorcajau increased the yield, maximum yield and biological efficiency at $300 \mathrm{mg} / \mathrm{l}$ (Sharma ,2007). Application of vitamins to the growing media increased hyphal growth and productivity of Flammaline velutipes (Chen Hairong et al., 1995). Exogenous supply of vitamins significantly enhanced the growth of fungus (Jonathan and Fasidi, 2003).

Halder and Samajpati (2001) studied the effect of riboflavin, inositol, thiamine, pyridoxine, ascorbic acid, para- amiobenzoic acid and biotin on growth and productivity by the mycelia of $G$. chrysomyces, leucocoprinus birnbaumii and leucocoprinus cepaestipes under submerged culture, all the three mushrooms required riboflavin for growth and protein production. The mushrooms is auto trophic for thiamine and pyridoxine, other vitamins have negligible effects.

Amino acids is a well known bio-stimulant which has positive effects on plant growth, yield and significantly mitigates the injuries caused by abiotic stresses (Kowalczyk and Zielony 2008). Manjunathan and Kaviyarasan (2011) on Lentinus tuberregium (Fr.) indicated that Glycine proved to be the best amino acid; this is followed by L-ornithine mono hydrochloride. Basal 
medium supplemented with pyridoxine and thiamine gave the best growth of Pleurotus florida compared to the rest vitamin source (Adenipekun and Gbolagade 2006). Chandra and Purkayastha (1977) reported that asparagine and aspartic acid have been employed in increasing the mycelial growth and fruit body production in Agaricus bisporus.

This study aimed to investigate the effect of application with amino acids as well as vitamin B complex to the rice straw substrate on the yield and its components, physical characters and chemical constituents of oyster mushroom fruit bodies.

\section{MATERIALS AND METHODS}

This work was carried out in Private Farm at Kaffer Saker, Sharkia Governorate, during the period between 2009 and 2010 seasons, to study the effect of application with amino acids as well as vitamin B complex to the rice straw substrate on the yield and its components, physical characters and chemical constituents of oyster mushroom fruit bodies.

This experiment included ten treatments as follows: 1- Rice straw (control)

2- Rice straw + V.B complex $100 \mathrm{ppm}$

3- Rice straw + V.B complex 200 ppm

4- Rice straw + V.B complex $400 \mathrm{ppm}$

5- Rice straw + amino acids $100 \mathrm{ppm}$

6- Rice straw + amino acids $200 \mathrm{ppm}$

7- Rice straw + amino acids 400 ppm

8- Rice straw + Vit.B complex 100 ppm + amino acids 100 ppm

9- Rice straw + Vit.B complex $200 \mathrm{ppm}+$ amino acids $200 \mathrm{ppm}$ and 10- Rice straw + Vit.B complex 400 ppm + amino acids 400 ppm The source of amino acids was Amino18 compound which produced by Arab Co. for pharmaceuticals \& Medicinal plants MEPACO- Egypt. Every capsule contains several amino acids: Essential amino acids; i.e., isolucine $4.83 \mathrm{mg}$, leucine $9.73 \mathrm{mg}$, lysine $12.86 \mathrm{mg}$, hydroxy lysine $2.81 \mathrm{mg}$, methionine 2.5 $\mathrm{mg}$, phenylalanine $6.5 \mathrm{mg}$, threonine $6.4 \mathrm{mg}$, and valine $7.65 \mathrm{mg}$. Non essential amino acids; i.e., arginine $25.47 \mathrm{mg}$, histadine $2.25 \mathrm{mg}$, glycine $68.24 \mathrm{mg}$, alanine $28.66 \mathrm{mg}$, serine $25.47 \mathrm{mg}$, tyrosine $0.85 \mathrm{gm}$, aspartic $18.91 \mathrm{mg}$, glutamic $32.66 \mathrm{mg}$, proline $45.02 \mathrm{mg}$ and hydroxy proline. The source of Vitamin B complex was Trivarol compound which produced by Memphis Co. for Pharma. \& Chemical Ind. - Cairo-Egypt. Every tablet contains Vitamin $B_{1}$ at $125 \mathrm{mg}$, Vitamin $B_{6}$ at $125 \mathrm{mg}$, Vitamin $B_{12}$ at $125 \mathrm{mg}$ and Folic acid at $0.5 \mathrm{mg}$.

\section{Spawning}

Rice straw was chopped into particles $(15-20 \mathrm{~cm})$ and soaked in tap water for 12 hours, then left to drain the excess water, after that it was pasteurized in life steam system at $80-90^{\circ} \mathrm{C}$ for 6 hours. These pasteurized rice straw were left to reach to room temperature (Zadrazil, 1978).

After pasteurization the rice straw and adding the supplements to it (powder or spraying) the substrate were get out and spread in a $10 \mathrm{~cm}$ layer 
thickness four layers into polyethylene bags $60 \mathrm{~cm}$ in depth $\times 40 \mathrm{~cm}$ diameter, every bag contains $1 \mathrm{Kg}$ dry weight from rice straw (about $3 \mathrm{Kg}$ wet rice straw) and the spawn was distributed over each layer at the rate of $15 \%$ $(\mathrm{w} / \mathrm{w})$ (this equal $150 \mathrm{~g}$ spawn per bag).

\section{Mycelial growth}

The inoculated polyethylene bags were transferred to the incubation room at the temperature $25 \pm 3{ }^{\circ} \mathrm{C}$ with less ventilation and darkness till full colonization (two-three weeks). Then the polyethylene bags were pinned and transferred to the production room, where the temperature was $20 \pm 3{ }^{\circ} \mathrm{C}$ and relative humidity was maintained to about $80-90 \%$ using a foggy system.

The polyethylene bags were perforated to have enough aeration needed for fungal growth; the holes were $1 \mathrm{~cm}$ diameter and were distributed as 10 $\mathrm{cm}$ between each others.

In this study, the source of pleurotus florida (strain 238) was the Research Institute of Food Technology, Agriculture Research Center, Giza-Egypt.

\section{Data recorded}

Growth characters:

Two oyster mushroom clusters were randomly taken from each experimental unit of the first flush (first 15 days), and the following data were recorded: Cap diameter $(\mathrm{cm})$, Stipe diameter $(\mathrm{cm})$, Stipe length $(\mathrm{cm})$ and Cap weight $(\mathrm{g})$.

\section{Yield and its components:}

At suitable harvesting stage, all clusters were harvested and the following data were recorded:

1. Total fresh yield /bag.

2. Early yield / bag: it was calculated from the first 15 days from the beginning of harvesting.

3. Biological efficiency: It was defined as percentage of the fresh weight of harvested mushroom over the dry weight of substrate as explained by Zervakis and Balis (1992)

\section{B.E. $=\frac{\text { Fresh weight of total yield of mushroom }}{X 100}$ \\ Weight of dry substrate}

\section{Chemical constituents of fruit bodies:}

1- Dry matter percentage (D.M. \%): Samples of $100 \mathrm{gm}$ of fruit bodies from each replicate were dried in an electrical oven at $105^{\circ} \mathrm{C}$ till constant weight and $\mathrm{DM} \%$ was determined.

2- Minerals, protein and total carbohydrates: Samples of $50 \mathrm{gm}$ of fruit bodies from each replicate as well as samples of $200 \mathrm{gm}$ from each used substrate before spawning and after harvesting, were taken, then dried (by using an electrical oven) at $70^{\circ} \mathrm{C}$ till constant weight. The dried materials were grinded to a fine powder for the following chemical analysis. 
a- Minerals determination: Nitrogen, phosphorus and potassium were determined according to the methods described by Bremner and Mulvaney (1982), Olsen and Sommers (1982) and Jackson (1970), respectively.

b- Crude protein (\%):It was determined as nitrogen content and multiplied by 6.25 to convert it to equivalent protein content for fruit bodies and substrates, respectively(Fujihara et al., 1995).

C-Total carbohydrates (\%) :It was determined following the method described by (DÜbois et al., 1956).

Statistical Analysis: The obtained data were subjected to statistical analysis of variance according to Snedecor and Cochran (1982) and means separation were done according to Duncan (1958).

\section{RESULTS AND DISCUSSION}

\section{Growth characters of mushroom fruit bodies}

The obtained results in Table 1 showed the effect of amino acids and vitamin B complex to the rice straw on the growth characters of oyster mushroom in both seasons of study. It is quite clear from such results that, the highest values of cap diameter, were obtained when mushroom grown on rice straw + vit. B complex at 200 ppm + amino acids at 200 ppm followed by addition vit. B complex at $200 \mathrm{ppm}$ to rice straw. Moreover, the least treatment was control. It is clear from data in Table 1 that, the highest values of stipe diameter was more distinct by growing mushroom on rice straw and amino acids at $400 \mathrm{ppm}$ in first season, while the highest values in second season were recorded by growing mushroom on rice straw + vit. B complex at $200 \mathrm{ppm}+$ amino acids at $200 \mathrm{ppm}$. The minimum stipe diameter of fruit bodies was produced from rice straw only.

On the other hand, it is evident from Table 1 that using rice straw+ amino acids at $200 \mathrm{ppm}$ recorded the maximum values of stipe length in the first season, while in the second season growing mushroom on rice straw+ vit. $B$ complex at $200 \mathrm{ppm}+$ amino acids at $200 \mathrm{ppm}$ being the most effective and favorable treatment as well as recorded the maximum values of stipe length.

With regards to cap weight, the obtained results in Table 1 revealed that, the maximum values in this respect were recorded by growing mushroom on rice straw+ vit. B complex at $200 \mathrm{ppm}+$ amino acids at $200 \mathrm{ppm}$ followed by rice straw+ vit. B complex at $200 \mathrm{ppm}$. These results may be due to the physiological roles of amino acids which increased the metabolic processes (Fawzy, 2010), while, the beneficial effect of vitamin B complex on growth characters of mushroom may be due to that the vitamin $B$ complex components (vitamin $\mathrm{B}_{1}, \mathrm{~B}_{12}$ and folic acid) which can be improve the growth and productivity, essential biochemical function in amino acids metabolism and nucleic acids synthesis, regulation of DNA synthesis during cell division (Oertli ,1987; Andrew et al., 2000; and Smith et al., 2007).

Similar results were found by Sharma 2007, Chen Hairong et al., 1995, Jonathan and Fasidi, 2003 and Halder and Samajpati 2001, using vitamin B on mushroom and Manjunathan and Kaviyarasan (2011) on Lentinus 
tuberregium ( Fr.) (Adenipekun and Gbolagade 2006) on Pleurotus florida. Chandra and Purkayastha (1977) on Agaricus bisporus, using amino acids.

Yield and its components of fruit bodies

The obtained results in Table 2 showed the effect of amino acids and vitamin $\mathrm{B}$ complex to the rice straw on the yield and its components of oyster mushroom during the two seasons of study. Data of early yield/bag of oyster mushroom are given in Table 2. Results indicated that using rise straw + vit. B complex at $200 \mathrm{ppm}$ recorded the maximum values of early yield /bag followed by rise straw+ amino acids at 200 ppm as compared to other treatments.

It is quite clear from such data that, the total yield obtained from growing mushroom on rise straw + vit. B complex at $200 \mathrm{ppm}$ followed by rise starw + amino acids at $200 \mathrm{ppm}$. Also, the total yield obtained from growing mushroom on rise straw only was the least medium in this concern as compared to other treatments. From the abovementioned results it could be suggested that the superiority in total yield of mushroom fruits bodies may be due to the increase in the average cluster weight by such treatments.

Data of early yield/total yield (\%) of oyster mushroom are also given in Table 2. results indicated that using rice straw alone or with other treatments did not reflected any significant effect on early yield/total yield (\%), these results are true in both seasons of study.

It is clear from the data in Table 2 that growing mushroom on rice straw + vit. B complex at 200 ppm gave the best biological efficiency of $157.8 \%$ and $134.8 \%$ in the two seasons, respectively while, rice straw + amino acids at $200 \mathrm{ppm}$ recorded $150.1 \%$ and $130.2 \%$. On the other hand, rice straw only gave the lowest values of biological efficiency $121.8 \%$ and $101.0 \%$ in the two seasons, respectively. The increases in biological efficiency were about 36.0 and $33.8 \%$ for vit. B at 200 ppm over the control in the $1^{\text {st }}$ and $2^{\text {nd }}$ seasons, respectively.

These results agree with the findings of Sharma (2007), Chen Hairong et al., (1995), Jonathan and Fasidi (2003) and Halder and Samajpati (2001), using vitamin B on mushroom and Manjunathan and Kaviyarasan (2011) on Lentinus tuberregium (Fr.) (Adenipekun and Gbolagade 2006) on Pleurotus florida. Chandra and Purkayastha (1977) on Agaricus bisporus, using amino acids.

\section{Chemical constituents of mushroom fruit bodies}

The obtained results in Table 3 show the effect of addition amino acids and vitamin B complex to the rice straw on chemical constituents of mushroom fruit bodies i.e, total nitrogen, phosphorus and potassium percentage.

It is clear from the data that, all used treatments caused a significant and marked effect in this respect except rice straw alone and rice straw + vit. B complex at $100 \mathrm{ppm}$, the highest values of total nitrogen were obtained by cultivating oyster mushroom on rice straw + vit, B complex at $400 \mathrm{ppm}+$ amino acids at $400 \mathrm{ppm}$ and rice straw + vit, B complex at $200 \mathrm{ppm}+$ amino acids at $200 \mathrm{ppm}$ with non significant differences between them. These results were true in the two studies seasons. 
J. Plant Production, Mansoura Univ., Vol. 4 (10), October, 2013

1-2

1549 
Moreover, it is evident from the obtained results in Table 3 that, production of oyster mushroom on rice straw + vit, B complex at $400 \mathrm{ppm}+$ amino acids at $400 \mathrm{ppm}$ and rice straw + vit, B complex at $200 \mathrm{ppm}+$ amino acids at $200 \mathrm{ppm}$ significantly increased phosphorus percentage in fruit bodies over those produced by the other tested treatments with non significant differences between them, while, the lowest values in this connection were distinct via using rice straw alone.

The results in Table 3 indicated also that, using rice straw + vit, B complex at $400 \mathrm{ppm}+$ amino acids at $400 \mathrm{ppm}$ and rice straw + vit, B complex at $200 \mathrm{ppm}+$ amino acids at $200 \mathrm{ppm}$ being the most effective and favorable treatments, for increasing potassium percentage in fruit bodies as compared with the other tested treatments.

Similar results were found by Sharma (2007) and Halder and Samajpati (2001), using vitamin B on mushroom and Manjunathan and Kaviyarasan (2011) on Lentinus tuberregium (Fr.) (Adenipekun and Gbolagade 2006) on Pleurotus florida. Chandra and Purkayastha (1977) on Agaricus bisporus, using amino acids.

\section{Dry matter, total dry matter yield / bag, crude protein and total} carbohydrates

It could be noted from the presented data in Table 4 that using rice straw + vit, B complex at $400 \mathrm{ppm}+$ amino acids at $400 \mathrm{ppm}$ and rice straw + vit, B complex at $200 \mathrm{ppm}+$ amino acids at $200 \mathrm{ppm}$ recorded the highest dry matter percentage in fruit bodies with out significant differences between them. On the contrary, the lowest percentage of dry matter of fruit body was obtained by using rice straw substrate alone.

These results are in agreement with those reported by Kattab (2000) and Radwan (2005), who concluded that growing oyster mushroom on any substrate had high nitrogen content, gave fruit bodies containing high dry matter percentage in their tissues.

Furthermore, it is evident from the obtained results in Table 4 that cultivation of oyster mushroom on rice straw + vit. B complex at $400 \mathrm{ppm}$ and rice straw + vit. B complex at $200 \mathrm{ppm}$ produced the highest dry matter yield of fruiting bodies per bag compared to the other tested treatments. On the contrary, growing mushroom on rice straw alone recorded the lowest values and being the inferior treatments in this connection.

It could be noted from the data in Table 4 that, all used treatments caused a significant effect on protein content with non significant differences among them except rice straw alone and rice straw + vit, B complex at $100 \mathrm{ppm}$. The highest values of protein content were obtained by cultivating mushroom on rice straw + vit, $B$ complex at $400 \mathrm{ppm}+$ amino acids at $400 \mathrm{ppm}$ followed by rice straw + vit, B complex at $200 \mathrm{ppm}+$ amino acids at $200 \mathrm{ppm}$. On the contrary, the lowest protein percentage in fruit bodies was obtained when oyster mushroom was cultivated on rice straw alone, this might because rice straw as alone substrate contain little nitrogen content in it is tissues.

In this connection Qin et al., (1989) and Khattab (2000) concluded that crude protein percentage of fruit bodies varied with the different substrates. While, using substrates with high protein content in their tissues produced fruit bodies of high protein content 
J. Plant Production, Mansoura Univ., Vol. 4 (10), October, 2013

3-4 


\section{El-Sayed, Hala A. et al.}

With respect to the content of total carbohydrates in fruit bodies, it is quite clear from the presented data in Table 4 that, using rice straw + vit, B complex at $400 \mathrm{ppm}+$ amino acids at $400 \mathrm{ppm}$ and rice straw + vit, B complex at 200 ppm + amino acids at $200 \mathrm{ppm}$ recorded the maximum values in this respect, as compared with other treatments with out significant differences between them. The lowest values of total carbohydrates were more achieved by using rice straw alone. These results hold true in the two seasons of study.

\section{RECMMENDATION}

From the above mentioned results and discussion, it could be recommended that using rice straw + vitamin B complex at $200 \mathrm{ppm}+$ +amino acids at $200 \mathrm{ppm}$ and rice straw + vitamin B complex at $400 \mathrm{ppm}+$ +amino acids at $400 \mathrm{ppm}$ in most cases as a treatments were more effective on growth, yield and chemical constituents of oyster mushroom in both seasons of study.

\section{REFERENCES}

Adenipekun ,C.O., and J.S. Gbolagade (2006). Nutritional Requirements of Pleurotus florida (Mont.) Singer, A Nigerian Mushroom. Pakistan Journal of Nutrition 5 (6): 597-600

Andrew WJ, C. Youngkoo, X. Chen, SG. Pandalai (2000). Vicissitudes of a vitamin. Recent Res. Dev. Phytochem., 4: 89-98.

Atikpo M, O. Onokpise, M .Abazinge, C. Louime, M. Dzomeku, L .Boateng Awumbilla (2008). Sustainable mushroom production in Africa: A case study in Ghana. Afr. J. Biotechnol. 7:249 -253.

Beetz A., and M. Kustudia (2004). Mushroom Cultivation and Marketing. Horticulture Production Guide, National Sustainable Agriculture Information Service.

Bremner, J. M., and C. S. Mulvaney (1982) Total nitrogen. In: Page, A. L., R. H. Miller, and D. R. Keeney (Eds). Methods of soil analysis . Part 2. Amer. Soc. Agron. Madison, W. I. USA pp. 595-624.

Chandra, A., Purkayastha, R, P., (1977).Physiological studies on Indian mushrooms. Transactions of British Mycological Society, 69: $63-70$.

Chang, S. T., O. W. Lau and K. Y. Cho (1981). The cultivation and nutritional value of pleurotus sajor-caju. European J. of Appl. Microbiol. and biotechnol. 12: 58-62.

Chen Hairong, Y. Jiagqiang, Y. Yi and H. Danfeng (1995). Research into improved techniques for high yield of Flammulina velutipe and the reuse of waste substrate. J. of Shanghai Agric. College. 13(2):106-112.

Dubois, M., K. A.Gilles, J. K.Hamilton, P. A.Rebers, and F. Smith (1956). Colorimetric method for determination of sugars and related substances. Analytical Chemistery 28:350-356.

Duncan, D. B. (1958) Multiple range and multiple F test. Biometrics 11: 1-42. 
DÜndar, A. and A. Yildiz (2009). A comparative study on pleurotus ostreatus (Jacq.) P. Kumm. cultivated on different agricultural lignocellulosic wastes. Turk. J. Biol., 33:171-179.

Fujihara, S., A. Kasuga, Y. Aoyagi, and T. Sugahara (1995) Nitrogen to protein conversion factors for some common edible mushrooms. Journal of Food Science 60 (5):1045-1047.

Halder, M., and N. Samajpati (2001). Effect of vitamins on growth and protein production by mycelia of three tropical mushrooms under submerged culture. J. of mycopathological Res. 39 (2): 73-76.

Imtiaj A, and S.A. Rahman (2008). Economic viability of mushroom cultivation to poverty reduction in Bangladidesh. Trop. Subtrop. Agroecosyst. 8:93-99.

Jackson, M. L. (1970) Soil Chemical Analysis . Prentice Hall. Englewood Gilles, N. J.

Jonathan, S. G., and I. O. Fasidi (2003). Studies on pstahyerella atroumbonata (Pegler), a Nigerian edible fungus. Food chemistry 81(4): 481-484.

Jose, N., and K. K., Janardhanan, (2000). Antioxidant and antitumour activity of Pleurotus florida. Curr. Sci. 79 (7): 941-943.

Khattab, E. A. K.(2000). Effect of some cultural practices on mushroom production. M.Sc. Thesis, Fac. Agric., Munufiya Univ., Egypt.

Kowalczyk, K. and T. Zielony, (2008). Effect of Aminoplant and Asahi on yield and quality of lettuce grown on rockwool. Conf.of biostimulators in modern agriculture, 7-8 Febuary 2008, Warsaw, Poland.

Manjunathan J.,V. Kaviyarasan (2011). Optimization of mycelia growth and antimicrobial activity of new edible mushroom, Lentinus tuberregium (Fr.). Tamil Nadu.,India. International Journal of PharmTech Research 3: (1) 497-504.

Moda, E. M., J. Horii, M. H. F. Spoto (2005). Edible mushroom pleurotus sajor-caju. Production on washed and supplemented sugarcane bagasse. Sci. Agric., 62 (2): 127-132.

Oertli, J. J. (1987). Exogenous application of vitamins as regulators for growth and development of plants- A review Zeitschrift fur pflanzenernahrung und Bodenk, 150 (6): 375-391.

Olsen, S.R., and L.E. Sommers (1982). Phosphorus. P. 403-430 In A.L. Page et al. (ed.) Methods of soil analysis. Part 2. 2nd ed. Agronomy Monogr. 9. ASA and SSSA, Madison, WI.

Qin, S. X., H. L. Zhang, L. K. Ren, and X. J. Yan (1989). Effects of different cultivation materials on nutritive composition of Pleurotus fruiting bodies. Edible Fungi of China. 3:12-13. (C.F. Hort. Abstr, 61: 2886).

Radwan, M. M. (2005) Studies on mushroom production. M. Sc. Thesis, Fac. Agric., Zagazig Univ., Egypt.

Sharma, P. K. (2007).Effect of chemical supplementation on the yield and biological efficiency of Pleurotus sajor caju grown in three different lignocellulosic wastes in Chhattisgarh, India.Asian J. of Bio science, 2 (1/2): 131-136. 


\section{El-Sayed, Hala A. et al.}

Smith, A.G, M.T. Croft, M. Moulin and M.E. Webb (2007). Plants need their vitamins too. Physiol. Metab., 10(3): 266-275.

Snedecor, G. W. and W. G. Cochran (1982). Statistical methods . $7^{\text {th }}$ ed. The lowa State Univ. Press, Amer . lowa, USA.

Zadrazil, F. (1978) Cultivation of Pleurotus. Pages 521 -557. In: Changm S. T. and Hayes. A. W. The Biology and cultivation of Edible mushrooms Academic Press. New York. 819 P.

Zervakis, G. and C. Balis(1992). Comparative study on cultural characters of Pleurotus species under the different substrates and fruiting temperature .Micol.Neotop.Appl., 5:39-47.

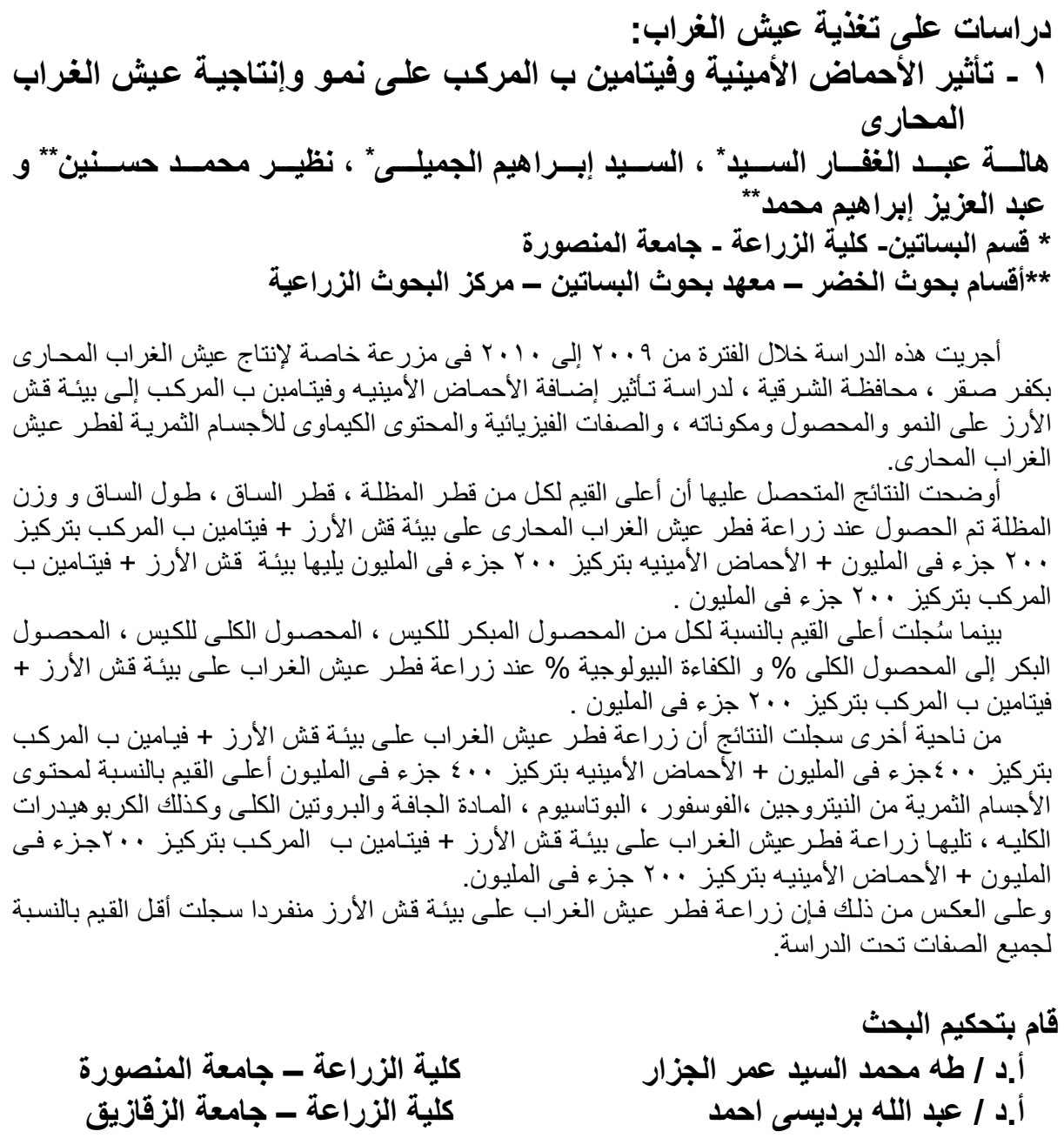

كلية الزراعة - جامعة المنصورة كلية الزراعة - جامعة الزقازيق جاعن 
J. Plant Production, Mansoura Univ., Vol. 4 (10), October, 2013 
Table 1: Effect of amino acids and vitamin B complex to the rice straw substrate on cap diameter, stipe diameter, stipe length and cap weight of oyster mushroom fruit bodies during 2009 and 2010 seasons

\begin{tabular}{|c|c|c|c|c|c|c|c|c|c|c|c|c|c|c|c|c|}
\hline \multirow{3}{*}{\begin{tabular}{|l} 
Treatments \\
Growth media(W/W) \\
Rice straw \\
\end{tabular}} & \multicolumn{4}{|c|}{$\begin{array}{l}\text { Cap diameter } \\
\text { (cm) }\end{array}$} & \multicolumn{4}{|c|}{$\begin{array}{c}\text { Stipe diameter } \\
\text { (cm) }\end{array}$} & \multicolumn{4}{|c|}{$\begin{array}{l}\text { Stipe length } \\
(\mathbf{c m})\end{array}$} & \multicolumn{4}{|c|}{ Cap weight (gm) } \\
\hline & \multicolumn{2}{|c|}{$\begin{array}{c}1^{\text {st }} \\
\text { season }\end{array}$} & \multicolumn{2}{|c|}{$\begin{array}{c}2^{\text {nd }} \\
\text { season }\end{array}$} & \multicolumn{2}{|c|}{$\begin{array}{c}1^{\text {st }} \\
\text { season }\end{array}$} & \multicolumn{2}{|c|}{$\begin{array}{c}2^{\text {nd }} \\
\text { season }\end{array}$} & \multicolumn{2}{|c|}{$\begin{array}{c}1^{\text {st }} \\
\text { season }\end{array}$} & \multicolumn{2}{|c|}{$\begin{array}{c}2^{\text {nd }} \\
\text { season }\end{array}$} & \multicolumn{2}{|c|}{$\begin{array}{c}1^{\text {st }} \\
\text { season }\end{array}$} & \multicolumn{2}{|c|}{$\begin{array}{c}2^{\text {nd }} \\
\text { season }\end{array}$} \\
\hline & 6.50 & $\mathrm{c}$ & 6.40 & $\mathrm{c}$ & 1.06 & $\mathrm{~d}$ & 1.09 & $\mathrm{ab}$ & 4.10 & $\mathrm{ab}$ & 4.13 & $\mathrm{~b}$ & 10.9 & de & 10.2 & $\mathrm{c}$ \\
\hline Rice straw + vitamin B complex 100ppm & 6.58 & $\mathrm{c}$ & 6.70 & $\mathrm{bc}$ & 1.17 & $b-d$ & 1.01 & $\mathrm{~b}$ & 4.28 & $\mathrm{ab}$ & 3.87 & $\mathrm{~b}$ & 10.9 & de & 11.0 & c \\
\hline Rice straw + vitamin B complex 200ppm & 7.57 & $a b$ & 7.18 & $a b$ & 1.26 & $a-c$ & 1.23 & $a b$ & 4.54 & $a b$ & 4.25 & $a b$ & 14.9 & $\mathrm{~b}$ & 13.6 & $\mathrm{~b}$ \\
\hline Rice straw + vitamin B complex 400ppm & 7.50 & $a b$ & 6.92 & $a-c$ & 1.26 & $a-c$ & 1.25 & $a b$ & 5.09 & $\mathrm{a}$ & 4.03 & $\mathrm{~b}$ & 13.4 & $\mathrm{bc}$ & 12.2 & $\mathrm{bc}$ \\
\hline Rice straw+ amino acids 100ppm & 7.43 & $a b$ & 6.75 & $a-c$ & 1.17 & $b-d$ & 1.18 & $a b$ & 4.37 & $a b$ & 4.38 & $a b$ & 14.0 & $\mathrm{bc}$ & 10.7 & $\mathrm{c}$ \\
\hline Rice straw+ amino acids 200ppm & 7.15 & $\mathrm{bc}$ & 6.80 & $a-c$ & 1.32 & $a-c$ & 1.23 & $\mathrm{ab}$ & 5.05 & $\mathrm{a}$ & 4.20 & $\mathrm{~b}$ & 14.7 & $\mathrm{bc}$ & 12.6 & $\mathrm{bc}$ \\
\hline Rice straw+ amino acids $400 \mathrm{ppm}$ & 6.92 & $\mathrm{bc}$ & 6.87 & $a-c$ & 1.43 & $\mathrm{a}$ & 1.10 & $a b$ & 3.86 & $\mathrm{~b}$ & 4.10 & $a b$ & 12.8 & $\mathrm{~cd}$ & 11.9 & bc \\
\hline Rice straw+ vit. B 100ppm +amino100ppm & 7.27 & $a-c$ & 6.28 & $\mathrm{C}$ & 1.16 & $\mathrm{~cd}$ & 1.14 & $a b$ & 4.53 & $a b$ & 4.35 & $a b$ & 10.7 & $\mathrm{e}$ & 11.2 & $\mathrm{bc}$ \\
\hline Rice straw+ vit. B 200ppm +amino200ppm & 8.03 & $\mathrm{a}$ & 7.42 & $\mathrm{a}$ & 1.34 & $\mathrm{ab}$ & 1.30 & $\mathrm{a}$ & 4.82 & $a b$ & 5.25 & $\mathrm{a}$ & 17.9 & $\mathrm{a}$ & 17.6 & $\mathrm{a}$ \\
\hline Rice straw+ vit. B 400ppm +amino400ppm & 6.58 & c & 6.91 & $a-c$ & 1.21 & $b-d$ & 1.17 & $a b$ & 3.63 & $\mathrm{~b}$ & 3.82 & $\mathrm{~b}$ & 11.2 & de & 12.4 & bc \\
\hline
\end{tabular}

Values having the same alphabetical letter(s) did not significantly differ at 0.05 level of significance according to Duncan's multiple range tes

Table 2: Effect of amino acids and vitamin B complex to the rice straw substrate on early yield, total yield and Biological efficiency of oyster mushroom during 2009 and 2010 seasons

\begin{tabular}{|c|c|c|c|c|c|c|c|c|c|c|c|c|c|c|c|c|}
\hline \multirow{3}{*}{\begin{tabular}{|l} 
Treatments \\
Growth media(W/W) \\
Rice straw
\end{tabular}} & \multicolumn{4}{|c|}{$\begin{array}{c}\text { Early yield/ bag } \\
(\mathrm{gm})\end{array}$} & \multicolumn{4}{|c|}{$\begin{array}{c}\text { Total yield/ bag } \\
(\mathrm{gm})\end{array}$} & \multicolumn{4}{|c|}{$\begin{array}{l}\text { Early yield/ Total } \\
\text { yield\% }\end{array}$} & \multicolumn{4}{|c|}{ Biological efficiency\% } \\
\hline & \multicolumn{2}{|c|}{$\begin{array}{c}1^{\text {st }} \\
\text { season }\end{array}$} & \multicolumn{2}{|c|}{$\begin{array}{c}2^{\text {nd }} \\
\text { season }\end{array}$} & \multicolumn{2}{|c|}{$\begin{array}{c}1^{\text {st }} \\
\text { season }\end{array}$} & \multicolumn{2}{|c|}{$\begin{array}{c}2^{\text {nd }} \\
\text { season }\end{array}$} & \multicolumn{2}{|c|}{$\begin{array}{c}1^{\text {st }} \\
\text { season }\end{array}$} & \multicolumn{2}{|c|}{$\begin{array}{c}2^{\text {nd }} \\
\text { season }\end{array}$} & \multicolumn{2}{|c|}{$\begin{array}{c}1^{\text {st }} \\
\text { season }\end{array}$} & \multicolumn{2}{|c|}{$\begin{array}{c}2^{\text {nd }} \\
\text { season }\end{array}$} \\
\hline & 621.7 & $d$ & 520.0 & c & 1218.3 & $d$ & 1010.0 & $\mathrm{~b}$ & 51.0 & a & 52.6 & $a$ & 121.8 & $d$ & 101.0 & $\mathrm{~b}$ \\
\hline Rice straw + vitamin B complex 100ppm & 840.0 & $a b$ & 655.0 & a-c & 1516.7 & $a b$ & 1215.0 & $\mathrm{ab}$ & 55.4 & $a$ & 53.9 & $a$ & & $a b$ & 121.5 & $a b$ \\
\hline Rice straw + vitamin B complex 200ppm & 895.0 & $a$ & 716.7 & $\mathrm{a}$ & 1578.3 & $\mathrm{a}$ & 1348.3 & $\mathrm{a}$ & 56.9 & $a$ & 53.3 & $a$ & 157.8 & $\mathrm{a}$ & 134.8 & $a$ \\
\hline Rice straw + & & $a-c$ & 606.7 & $a-c$ & & $a b$ & & $a b$ & 55.1 & $\mathrm{a}$ & 51.2 & $a$ & & $a b$ & 117.8 & $a b$ \\
\hline Rice straw+ amino acids 100ppm & 740.0 & b-d & 591.7 & a-c & 1490.0 & $a b$ & 1176.7 & $a b$ & 49.7 & $\mathrm{a}$ & 50.6 & & 149.0 & $a b$ & 117.7 & $a b$ \\
\hline Rice straw+ amino acids 200ppm & 753.3 & $a-d$ & 695.0 & $\mathrm{a}$ & 1505.0 & $a b$ & 1301.7 & $\mathrm{a}$ & 46.1 & $\mathrm{a}$ & 53.9 & $\mathrm{a}$ & 150.1 & $a b$ & 130.2 & $a$ \\
\hline Rice straw+ amino acids $400 \mathrm{ppm}$ & 731.7 & $b-d$ & 675.0 & $a b$ & 1460.0 & $a-c$ & 1266.7 & $a$ & 55.5 & $a$ & 53.3 & $a$ & 146.2 & $a-c$ & 126.7 & $a$ \\
\hline Rice straw+ vit. B & & $\mathrm{d}$ & 640.0 & $a-c$ & $1411.7 \mathrm{k}$ & $\mathrm{b}-\mathrm{c}$ & 1191.7 & $a b$ & 46.9 & $\mathrm{a}$ & 54.2 & $\mathrm{a}$ & 141.2 & $\mathrm{bc}$ & 119.2 & $a b$ \\
\hline Rice straw+ vit. B 200ppm +amino2 & 668.7 & $\mathrm{~cd}$ & 678.0 & $a b$ & $1421.7 \mathrm{k}$ & b-c & 1293.3 & a & 49.1 & $a$ & 52.6 & $a$ & 142.2 & $\mathrm{bc}$ & 129.3 & $a$ \\
\hline Rice straw+ vit. B 400ppm +amino400ppm & 630.0 & $\mathrm{~d}$ & 551.7 & $\mathrm{bc}$ & 1336.7 & cod & 1133.3 & $a b$ & 47.7 & $\mathrm{a}$ & 49.4 & & 133.7 & $\mathrm{~cd}$ & 113.3 & $a b$ \\
\hline
\end{tabular}

range test 
Table 3: Effect of amino acids and vitamin B complex to the rice straw substrate on nitrogen, phosphorus and potassium percentages in oyster mushroom fruit bodies during 2009 and 2010 seasons

\begin{tabular}{|c|c|c|c|c|c|c|c|c|c|c|c|c|}
\hline \multirow{3}{*}{$\begin{array}{l}\text { Treatments } \\
\text { Growth media(W/W) } \\
\text { Rice straw }\end{array}$} & \multicolumn{4}{|c|}{$\mathbf{N} \%$} & \multicolumn{4}{|c|}{$\mathbf{P} \%$} & \multicolumn{4}{|c|}{$\mathrm{K} \%$} \\
\hline & \multicolumn{2}{|c|}{$\begin{array}{c}1^{\text {st }} \\
\text { season }\end{array}$} & \multicolumn{2}{|c|}{$\begin{array}{c}2^{\text {nd }} \\
\text { season }\end{array}$} & \multicolumn{2}{|c|}{$\begin{array}{c}1^{\text {st }} \\
\text { season }\end{array}$} & \multicolumn{2}{|c|}{$\begin{array}{c}2^{\text {nd }} \\
\text { season }\end{array}$} & \multicolumn{2}{|c|}{$\begin{array}{c}1^{\text {st }} \\
\text { season }\end{array}$} & \multicolumn{2}{|c|}{$\begin{array}{c}2^{\text {nd }} \\
\text { season }\end{array}$} \\
\hline & 4.67 & $\mathrm{c}$ & 4.40 & c & 0.938 & $\mathrm{~h}$ & 0.931 & $\mathrm{e}$ & 3.98 & $\mathrm{~g}$ & 3.91 & $\mathrm{e}$ \\
\hline Rice straw + vitamin B complex 100ppm & 5.60 & $\mathrm{~b}$ & 5.40 & $\mathrm{~b}$ & 1.111 & $\mathrm{~g}$ & 0.983 & de & 4.80 & 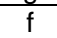 & 4.73 & $\mathrm{~d}$ \\
\hline Rice straw + vitamin B complex 200ppm & 5.72 & $a b$ & 5.72 & $a b$ & 1.128 & $\mathrm{fg}$ & 0.998 & d & 4.83 & ef & 4.77 & $d$ \\
\hline Rice straw + vitamin B complex 400ppm & 5.77 & $a b$ & 5.76 & $a b$ & 1.141 & f & 1.115 & c & 4.87 & $\mathrm{e}$ & 4.84 & $\mathrm{~cd}$ \\
\hline Rice straw+ amino acids 100ppm & 5.81 & $a b$ & 5.77 & $a b$ & 1.162 & $\mathrm{e}$ & 1.150 & $\mathrm{bc}$ & 4.93 & d & 4.91 & $\mathrm{bc}$ \\
\hline Rice straw+ amino acids 200ppm & 5.90 & $a b$ & 5.87 & $\mathrm{a}$ & 1.188 & $\mathrm{~cd}$ & 1.180 & $a b$ & 5.02 & c & 5.00 & $a b$ \\
\hline Rice straw+ amino acids 400ppm & 5.94 & $a b$ & 5.90 & $\mathrm{a}$ & 1.197 & $\mathrm{bc}$ & 1.192 & $a b$ & 5.09 & $\mathrm{~b}$ & 5.03 & $a b$ \\
\hline Rice straw+ vit. B 100ppm +amino100ppm & 5.84 & $a b$ & 5.88 & a & 1.175 & de & 1.171 & $\mathrm{a}-\mathrm{c}$ & 4.97 & $\mathrm{~cd}$ & 4.95 & $\mathrm{bc}$ \\
\hline Rice straw+ vit. B 200ppm +amino200ppm & 5.96 & $\mathrm{a}$ & 5.96 & $\mathrm{a}$ & 1.209 & $a b$ & 1.200 & $\mathrm{ab}$ & 5.12 & $\mathrm{ab}$ & 5.10 & $\mathrm{a}$ \\
\hline Rice straw+ vit. B 400ppm +amino400ppm & 6.06 & $a$ & 6.11 & $a$ & 1.219 & $\mathrm{a}$ & 1.213 & $\mathrm{a}$ & 5.16 & $\mathrm{a}$ & 5.13 & $a$ \\
\hline
\end{tabular}

Rice straw+ vit. B 400ppm +amino400ppm

ificantly differ at 0.05 level of significance according to Duncan's multiple range test

Table 4: Effect of amino acids and vitamin B complex to the rice straw substrate on dry matter, crude protein percent and carbohydrate percentage in fruit bodies during 2009 and 2010 seasons

\begin{tabular}{|c|c|c|c|c|c|c|c|c|c|c|c|c|}
\hline \multirow{3}{*}{$\begin{array}{l}\text { Treatments } \\
\text { Growth media(W/W) } \\
\text { Rice straw } \\
\end{array}$} & \multicolumn{4}{|c|}{ Dry matter (\%) } & \multicolumn{4}{|c|}{$\begin{array}{l}\text { Crude protein } \\
\text { (\%)as D.W. basis }\end{array}$} & \multicolumn{4}{|c|}{$\begin{array}{l}\text { Total Carbohydrates } \\
\text { (\%)as D.W. basis }\end{array}$} \\
\hline & \multicolumn{2}{|c|}{$\begin{array}{c}1^{\text {st }} \\
\text { season }\end{array}$} & \multicolumn{2}{|c|}{$\begin{array}{c}2^{\text {nd }} \\
\text { season }\end{array}$} & \multicolumn{2}{|c|}{$\begin{array}{c}1^{\text {st }} \\
\text { season }\end{array}$} & \multicolumn{2}{|c|}{$\begin{array}{c}2^{\text {nd }} \\
\text { season }\end{array}$} & \multicolumn{2}{|c|}{$\begin{array}{c}1^{\text {st }} \\
\text { season }\end{array}$} & \multicolumn{2}{|c|}{$\begin{array}{c}2^{\text {nd }} \\
\text { season }\end{array}$} \\
\hline & 6.60 & $\mathrm{e}$ & 6.25 & $\mathrm{e}$ & 29.2 & $\mathrm{c}$ & 27.5 & $\mathrm{c}$ & 47.75 & $\mathrm{~g}$ & 46.89 & $\mathrm{~d}$ \\
\hline Rice straw + vitamin B complex 100ppm & 8.12 & $\mathrm{~cd}$ & 8.18 & $\mathrm{~cd}$ & 35.0 & $\mathrm{~b}$ & 33.7 & $\mathrm{~b}$ & 49.26 & f & 48.48 & c \\
\hline Rice straw + vitamin B complex 200ppm & 9.72 & $\mathrm{~b}$ & 9.67 & $\mathrm{~b}$ & 35.7 & $a b$ & 35.7 & $a b$ & 49.33 & f & 49.34 & $\mathrm{~b}$ \\
\hline Rice straw + vitamin B complex 400ppm & 10.33 & $a b$ & 10.25 & $a b$ & 36.1 & $a b$ & 36.0 & $a b$ & 49.47 & ef & 49.43 & $\mathrm{~b}$ \\
\hline Rice straw+ amino acids $100 p p m$ & 7.52 & d & 7.40 & d & 36.3 & $a b$ & 36.1 & $a b$ & 49.61 & de & 49.67 & $a b$ \\
\hline Rice straw+ amino acids 200ppm & 8.80 & c & 8.72 & c & 36.9 & $a b$ & 36.7 & $\mathrm{a}$ & 49.77 & $b-d$ & 49.72 & $a b$ \\
\hline Rice straw+ amino acids $400 \mathrm{ppm}$ & 9.89 & $\mathrm{~b}$ & 10.00 & $a b$ & 36.8 & $a b$ & 36.9 & $\mathrm{a}$ & 49.83 & $a-c$ & 49.76 & $\mathrm{ab}$ \\
\hline Rice straw+ vit. B 100ppm +amino100ppm & 8.69 & $\mathrm{C}$ & 8.58 & $\mathrm{C}$ & 36.5 & $a b$ & 36.7 & $\mathrm{a}$ & 49.67 & $\mathrm{~cd}$ & 49.63 & $a b$ \\
\hline Rice straw+ vit. B 200ppm +amino200ppm & 10.45 & $a b$ & 10.55 & $\mathrm{a}$ & 37.2 & $\mathrm{a}$ & 37.2 & $a$ & 49.91 & $a b$ & 49.91 & $a b$ \\
\hline Rice straw+ vit. B 400ppm +amino400ppm & 11.00 & $\mathrm{a}$ & 10.72 & $\mathrm{a}$ & 37.9 & $\mathrm{a}$ & 38.2 & $\mathrm{a}$ & 49.98 & $\mathrm{a}$ & 50.04 & $\mathrm{a}$ \\
\hline
\end{tabular}

Rice straw+ vit. B 400ppm +amino400ppm

test
tes havi 
J. Plant Production, Mansoura Univ., Vol. 4 (10): 1543 - 1554, 2013 